\title{
HUBUNGAN PENGETAHUAN DENGAN SIKAP REMAJA PUTRI TENTANG KEHAMILAN REMAJA DI SMK N 2 TABANAN
}

\author{
Hesteria Friska Armynia Subratha ${ }^{1,2}$, Cokorda Istri Mita Pemayun ${ }^{1,2}$, Ni Luh Jinhi Antari ${ }^{1,2}$ \\ ${ }^{1}$ Program Studi DIII Kebidanan, ${ }^{2}$ Sekolah Tinggi Ilmu Kesehatan Advaita Medika Tabanan \\ Korespodensi penulis: hesteria.friska@yahoo.com
}

\begin{abstract}
Abstrak
Latar belakang dan tujuan: Dampak kehamilan resiko tinggi pada remaja yaitu seperti keguguran, pesalinan yang belum cukup bulan, mudah terjadinya infeksi, keracunan kehamilan dan kematian ibu yang tinggi. Berdasarkan studi pendahuluan di SMK N 2 Tabanan tahun 2016 didapatkan 5 orang siswi mengalami kehamilan usia dini. Penelitian ini bertujuan ddduntuk mengetahui tingkat pengetahuan remaja putri tentang kehamilan remaja, sikap remaja putri tentang kehamilan remaja dan mengetahui hubungan pengetahuan dengan sikap remaja tentang kehamilan remaja.

Metode: Penelitian ini merupakan penelitian kuantitatif menggunakan rancangan crosss sectional. Penelitian ini dilakukan pada tanggal 9 Juli 2018. Sempel dalam penelitian ini yaitu seluruh siswi kelas XI SMK N 2 Tabanan yang berjumlah 41 responden. Cara pengambilan sampel dalam penelitian ini menggunakan teknik simple random sampling. Data dikumpulkan dengan menggunakan kuesioner dan teknik analisa data menggunakan uji korelasi sperman rank (Rho) dengan bantuan SPSS.
\end{abstract}

Hasil: Hasil penelitian menunjukkan bahwa 63\% responden berpengetahuan baik, $29 \%$ berpengetahuan cukup, dan $7 \%$ berpengetahuan kurang. Berdasarkan hasil uji kolerasi yaitu ada hubungan yang cukup kuat antara pengetahuan dengan sikap remaja putri tentang kehamilan remaja di SMK N 2 Tabanan yaitu sebesar 62,7\%.

Simpulan: ada hubungan pengetahuan dengan sikap remaja putri tentang kehamilan remaja di SMK N 2 Tabanan.

Kata kunci : Pengetahuan, Sikap, Remaja Putri, Kehamilan Remaja

\section{Pendahuluan}

Masa remaja merupakan masa peralihan dari anak-anak menuju dewasa. Saat masa peralihan ini, sering ditemukan remaja yang berperilaku menyimpang seperti merokok, seks bebas, tindakan kriminal dan penggunaan obat-obatan terlarang. Jiwa yang masih labil dalam upaya pencarian jati diri dari remaja, dapat meningkatkan rasa ingin tahu dan cenderung selalu ingin mencoba hal yang baru. Riset Kesehatan Dasar (Riskesdas) tahun 2013, melaporkan bahwa $23,9 \%$ remaja menikah pada umur 15-19 tahun dan $2,6 \%$ perempuan menikah pertama kali pada umur kurang dari 15 tahun. Akibatnya, angka kehamilan perempuan pada umur kurang dari 15 tahun adalah 2,68\% dan $1,97 \%$ pada umur 15-19 tahun (Kementerian Kesehatan RI, 2013).

Badan Koordinasi Keluarga Berencana Nasional (BKKBN) tahun 2013, menyatakan bahwa dari jumlah penduduk remaja yang berusia 14-19 tahun, terdapat 34 juta atau 19,6\% mengalami Kehamilan Tidak Diharapkan (KTD) dan angka seks bebas diseluruh kota besar di Indonesia mencapai $50 \%$. Berdasarkan hasil survei tersebut, sekitar 30\% berakhir dengan pernikahan dini karena hamil pada usia yang sangat muda. Data Perkumpulan Keluarga Berencana Indonesia (PKBI) menyatakan bahwa KTD pada remaja memiliki kecenderungan 
meningkat. Tahun 2003 terdapat 92 kasus, tahun 2004 terdapat 101 kasus dan tahun 2010 terdapat 120 kasus. Studi kuantitatif yang dilakukan oleh PKBI pada tahun 2013 menyebutkan bahwa persentase KTD remaja tertinggi berada di Bali yaitu sebanyak 228 kasus (PKBI 2013).

Badan Koordinasi Keluarga Berencana Nasional (BKKBN) Bali tahun 2013, melalui program PKBI Bali yaitu Kita Sayang Remaja Youth Clinic (KYC) Provinsi Bali, mencatat, KTD di Bali sebanyak 177 kasus dengan rata-rata dalam satu bulan adalah 15 kasus. Tahun 2014, didapatkan 111 kasus dengan rata-rata kasus dalam satu bulan adalah 11 kasus. Data ini didapatkan dari remaja yang melakukan konseling ke KYC Provinsi Bali. Berdasarkan hasil penelitian Pusat Studi Kependudukan dan Kebijakan (PSKK) Universitas Gajah Mada (UGM) tahun 2013 yang dilakukan bersama dengan sebuah organisasi yang bergerak dalam bidang kemanusiaan terutama pada perlindungan dan pemberdayaan anak (Plan Indonesia), menemukan bahwa insiden kehamilan di luar nikah paling tinggi terdapat di Kabupaten Tabanan yaitu sekitar 66,7\% (Kisara Bali, 2013).

Dampak kehamilan usia dini meliputi seluruh aspek kehidupan remaja seperti aspek kesehatan, fisik, psikologis dan sosial. Kesehatan remaja dan anak yang dikandungnya berada dalam risiko tinggi, karena otot-otot rahim masih lemah, belum berkembang sempurna, dan secara mental juga belum dewasa. Banyak remaja yang melakukan pernikahan dengan terpaksa serta terkadang berakibat pada perceraian dan aborsi tidak aman (Sinclair, 2012). Hasil penelitian Sri Yuniarti pada tahun 2011, didapatkan bahwa pengetahuan remaja putri tentang kehamilan remaja berada pada kategori kurang yaitu 44,9\% dan sikap remaja berada pada kategori sikap negatif yaitu 52,6\%. Penelitian Nisa Molinda pada tahun 2010, didapatkan bahwa pengetahuan remaja putri tentang kehamilan berada pada kategori kurang yaitu 43\% dan sikap remaja putri berada pada kategori sikap negatif yaitu sebanyak $45 \%$.
Berdasarkan data dan pemaparan diatas, maka pengetahuan remaja tentang kehamilan usia dini sangat penting untuk mengurangi jumlah kasus kematian ibu dan bayi. Studi pendahuluan dengan melakukan wawancara kepada Guru Bimbingan dan Konseling (BK) di SMK N 2 Tabanan, terdapat 5 orang siswi yang mengalami kehamilan usia dini di tahun 2016, dan membuat siswi tersebut berhenti bersekolah. Berdasarkan pernyataan di atas, menarik bagi peneliti untuk mengetahui tentang hubungan pengetahuan dengan sikap remaja putri tentang kehamilan remaja di SMK N 2 Tabanan.

Penelitian ini bertujuan untuk mengetahui hubungan pengetahuan dengan sikap remaja putrid tentang kehamilan remaja.

\section{Metode Penelitian}

Penelitian ini adalah penelitian kuantitatif dengan rancangan cross sectional. Penelitian cross sectional (potong lintang) yaitu rancangan penelitian dengan melakukan pengukuran atau pengamatan saat bersamaan atau sekali waktu.

Populasi dalam penelitian ini adalah semua siswi kelas XI, JB 1, JB 2,JB 3, JB 4 dan JB 5 di SMK N 2 Tabanan dengan jumlah 68 orang. Setelah dimasukkan ke dalam rumus didapatkan jumlah sampel yang diambil sebanyak 41 orang.

Cara pengambilan sampel dalam penelitian ini adalah dengan teknik simple random sampling. Pengambilan simple random sampling adalah cara pengambilan sampel dari semua anggota populasi dilakukan secara acak tanpa memperhatikan strata yang ada. Cara memperoleh sampel secara random yaitu member nomor semua anggota populasi, kemudian membuat nomor-nomor pada kertas kecil, tempat dan dikocok. Kita melakukan pengocokan terus sampai diperoleh sejumlah kertas kecil yang bernomor sebanyak yang diperlukan. Variable dalam penelitian ini yaitu variabel bebas pengetahuan remaja putri tentang kehamilan remaja dan variable terikat adalah sikap remaja putri tentang kehamilan remaja. 
Untuk melakukan pengumpulan data, penelitian ini menggunakan alat pengumpulan data berupa kuesioner yang terdiri dari 255 pertanyaan dengan pertanyaan positif dan negatif. Untuk pertanyan postif jika jawaban benar skor 1 dan jawaban salah skor 0, sedangkan untuk pertanyaan negatif jawaban benar skor 0 dan jawaban salah skor 1 . Untuk sikap jika jawabannya sangat setuju skornya 5 , setuju skornya 4 , ragu-ragu skornya 3 , tidak setuju skornya 2 dan sangat tidak setuju skornya 1 .

Teknik analisis dalam penelitian ini adalah analisis univariat dan bivariat. Analisis univariat digunakan untuk mengetahui gambaran tentang distribusi dari tiap variable yang di teliti. Sedangkan analisis bivariat dalam penelitian ini menggunakan Korelasi Sperman Rank (Rho).

\section{Hasil dan Pembahasan}

Dari karakteristik responden menunjukkan bahwa sebagian besar responden berumur 17 tahun $(75,6 \%)$. Hasil penelitian juga menunjukkan sebagian besar responden tinggal dengan orang tuanya $(63,4 \%)$, dan $51,2 \%$ orang tua responden memiliki penghasilan lebih dari $\mathrm{Rp}$ 1.000.000.00. Berdasarkan tingkat pengetahuan dapat diketahui bahwa sebanyak
63\% responden memiliki pengetahuan baik dan hanya sebagian kecil responden yang memiliki pengetahuan kurang yaitu sebanyak $7 \%$. Sedangkan dilihat dari sikap remaja putri dapat diketahui bahwa dari 41 responden, tidak ada yang memiliki sikap negatif terhadap kehamilan remaja dan $46 \%$ responden memiliki sikap positif terhadap kehamilan remaja.

Dari uji analisis memaparkan bahwa $50,0 \%$ responden berpengetahuan baik cenderung memiliki sikap positif, sedangkan $66,7 \%$ responden berpengetahuan kurang cenderung memiliki sikap yang sangat positif. Nilai koefisien korelasi variabel pengetahuan terhadap sikap remaja putri tentang kehamilan remaja sebesar 0,627 dan bernilai positif. Dari nilai tersebut dapat diketahui bahwa hubungan antara pengetahuan remaja putri dan sikap remaja putri tentang kehamilan remaja adalah cukup kuat. Hubungan kedua variabel signifikan karena tampak nilai signifikansi sebesar 0,000 maka lebih kecil dari 0,05 sehingga $\mathrm{H}_{0}$ ditolak. Jadi dapat disimpulkan bahwa $\mathrm{H}_{1}$ diterima yang artinya variabel pengetahuan remaja putri berpengaruh secara signifikan pada variabel sikap remaja putri terhadap kehamilan remaja yaitu sebesar $62,7 \%$.

Tabel 1. Karakteristik Responden

\begin{tabular}{l|c}
\hline \multicolumn{1}{c}{ Keterangan } & $\mathbf{f}(\%)$ \\
\hline 1. Umur & $10(24,4 \%)$ \\
\hline a) 16 tahun & $31(75,6 \%)$ \\
\hline b) 17 tahun & $41(100 \%)$ \\
\hline Jumlah & $26(63,4 \%)$ \\
\hline 2. Jenis Tempat Tinggal & $15(36,6 \%)$ \\
\hline a) Orang Tua & $41(100 \%)$ \\
\hline b) Kos & $1(2,4 \%)$ \\
\hline Jumlah & $19(46,3 \%)$ \\
\hline 3. Penghasilan Orang Tua & $21(51,2 \%)$ \\
\hline a) <Rp 500.000.00 & $41(100 \%)$ \\
\hline b) Rp 500.000.00-Rp 1.000.000.00 & \\
\hline c) $>$ Rp 1.000.000.00 & \\
\hline
\end{tabular}

Tabel 2. Distribusi Frekuensi Tingkat Pengetahuan Remaja Putri tentang Kehamilan di SMA N 2 
Tabanan

\begin{tabular}{lc}
\hline \multicolumn{1}{c}{ Pengetahuan Remaja } & $\mathbf{f ( \% )}$ \\
\hline Baik $(76-100 \%)$ & $26(63 \%)$ \\
\hline Cukup $(56-75 \%)$ & $12(29 \%)$ \\
\hline Kurang $(<56 \%)$ & $3(7 \%)$ \\
\hline Total & $41(100 \%)$ \\
\hline
\end{tabular}

Tabel 3. Distribusi Frekuensi Sikap Remaja Putri tentang Kehamilan di SMA N 2 Tabanan

\begin{tabular}{lc}
\hline \multicolumn{1}{c}{ Sikap Remaja } & $\mathbf{f ( \% )}$ \\
\hline Sangat Negatif & $0(0 \%)$ \\
\hline Negatif & $12(29 \%)$ \\
\hline Positif & $19(46 \%)$ \\
\hline Sangat Positif & $10(24 \%)$ \\
\hline Total & $41(100 \%)$ \\
\hline
\end{tabular}

Tabel 4. Hubungan Pengetahuan dengan Sikap Remaja Putri tentang Kehamilan di SMA N 2 Tabanan

\begin{tabular}{|c|c|c|c|c|c|c|}
\hline \multirow[b]{2}{*}{ Pengetahuan } & \multicolumn{3}{|c|}{ Sikap Remaja Putri } & \multirow[b]{2}{*}{ Total } & \multirow[b]{2}{*}{$\boldsymbol{r}$} & \multirow[b]{2}{*}{$p$} \\
\hline & Negatif & Positif & $\begin{array}{l}\text { Sangat } \\
\text { Positif }\end{array}$ & & & \\
\hline Baik (f) $\%$ & $\begin{array}{c}10 \\
(38,5)\end{array}$ & $\begin{array}{c}13 \\
(50,0)\end{array}$ & $\begin{array}{c}3 \\
(11,5)\end{array}$ & $\begin{array}{c}26 \\
(100)\end{array}$ & 0,627 & 0,000 \\
\hline Cukup (f) \% & $\begin{array}{c}2 \\
(16,7)\end{array}$ & $\begin{array}{c}5 \\
(41,7)\end{array}$ & $\begin{array}{c}5 \\
(41,7)\end{array}$ & $\begin{array}{c}12 \\
(100)\end{array}$ & & \\
\hline Kurang (f) \% & $\begin{array}{c}0 \\
(0,0)\end{array}$ & $\begin{array}{c}1 \\
(33,3)\end{array}$ & $\begin{array}{c}2 \\
(66,7)\end{array}$ & $\begin{array}{c}3 \\
(100)\end{array}$ & & \\
\hline Total & $\begin{array}{c}12 \\
(29,3)\end{array}$ & $\begin{array}{c}19 \\
(46,3)\end{array}$ & $\begin{array}{c}10 \\
(24,4)\end{array}$ & $\begin{array}{c}41 \\
(100)\end{array}$ & & \\
\hline
\end{tabular}

a. Pengetahuan tentang Kehamilan Remaja

Hasil penelitian menunjukkan bahwa sebanyak $63 \%$ responden berpengetahuan baik. Hal ini sejalan dengan teori Notoatmojo tahun 2010, bahwa untuk memperoleh pengetahuan yang baik dipengaruhi oleh beberapa faktor seperti umur, pendidikan, lingkungan dan sosial ekonomi.

Penelitian memaparkan umur responden berada pada kisaran 16 - 17 tahun yang merupakan remaja lanjut. Pendidikan responden saat ini telah sampai pada tingkat SMK. Pendidikan yang tinggi dapat memberikan kesempatan dalam menjalin interaksi seseorang untuk mengadopsi informasi yang diperoleh dari hasil interaksi tersebut.

Berdasarkan jenis tempat tinggal $63,4 \%$ responden tinggal bersama orang tua mereka. Lingkungan keluarga yang harmonis berpengaruh terhadap proses masuknya informasi untuk seseorang yang berada dalam lingkungan tersebut. Sosial Ekonomi

Hasil penelitian menunjukkan bahwa $51,2 \%$ orang tua responden memiliki penghasilan lebih dari 1.000.000.00. Tingkat sosial ekonomi yang memadai dapat mendukung ketersediaan fasilitas untuk memperoleh pengetahuan, sehingga hal ini juga sangat mempengaruhi perolehan informasi dalam meningkatkan pengetahuan.

b. Sikap Remaja tentang Kehamilan Remaja Hasil penelitian menunjukkan bahwa $46 \%$ responden memiliki sikap positif dan $29 \%$ responden memiliki sikap negatif. Hal ini sejalan dengan teori dari Anzwar tahun 2009, yang menyatakan bahwa pengalaman pribadi akan membentuk dan mempengaruhi penghayatan seseorang terhadap stimulus 
sosial, sehingga pengalaman yang dilihat maupun dirasakan oleh seseorang akan memberikan tanggapan yang menjadi salah satu dasar terbentuknya sikap.

Selain itu faktor emosi dalam diri individu juga dapat mempengaruhi sikap dari seseorang. Tanggapan yang ditunjukkan seseorang dan merupakan bentuk dari pertahanan ego juga dapat mencerminkan sikap seseorang terhadap sesuatu, namun terkadang sikap ini hanya berlangsung sementara. Emosi yang ditunjukkan oleh responden dapat menentukan pilihan sikap, sehingga pengetahuan yang kurang juga bisa menunjukkan sikap yang sangat positif.

c. Hubungan Pengetahuan Dengan Sikap Remaja Putri Tentang Kehamilan Remaja

Hasil dari penelitian ini menunjukkan bahwa pengetahuan remaja putri berpengaruh positif dan signifikan terhadap sikap remaja putri tentang kehamilan remaja di SMK N 2 Tabanan tahun 2018. Hal ini ditunjukkan dengan uji hipotesis dan uji korelasi Spearman Rank sebesar 0,627 yang menunjukkan bahwa ada hubungan yang cukup kuat antara pengetahuan dengan sikap remaja putri tentang kehamilan remaja yaitu sebesar $62,7 \%$.

Hasil ini sejalan dengan penelitian Juliani tahun 2014, yang menyatakan bahwa $96,4 \%$ responden berpengetahuan baik yang memiliki sikap positif (kecenderungan menghindari perilaku seksual pranikah). Selain itu 25,0\% responden berpengetahuan kurang tetapi memiliki memiliki sikap positif (kecenderungan menghindari perilaku seksual pranikah), sehingga hasil penelitian ini menunjukan bahwa terdapat hubungan yang signifikan antara pengetahuan dengan sikap remaja terhadap perilaku seksual pranikah.

Penelitian lain yang mendukung penelitian ini yaitu penelitian Dewi tahun 2008, menyatakan bahwa sebanyak 88,7\% remaja bersikap positif terhadap seks pranikah (kecenderungan menghindari perilaku seksual pranikah). Hasil lain juga didapatkan 9,7\% responden berpengetahuan kurang tetapi memiliki perilaku negatif dan $21,4 \%$ remaja memiliki perilaku yang positif. Hasil penelitian serupa juga dikemukakan oleh Devi Arista tahun 2013, menyatakan bahwa $62,1 \%$ responden memiliki pengetahuan tinggi terhadap perilaku yang beresiko terjadinya KTD dan 9,5\% responden memiliki pengetahuan rendah terhadap terjadinya KTD.

\section{Simpulan}

Berdasarkan hasil penelitian yang telah dilakukan dapat disimpulkan yaitu sebanyak 63\% tingkat pengetahuan remaja putri tentang kehamilan remaja termasuk dalam kategori baik, sebanyak 46\% sikap remaja putri termasuk kategori sikap positif. Pengetahuan remaja putri berpengaruh positif dan signifikan terhadap sikap remaja putri tentang kehamilan remaja dan ada hubungan yang cukup kuat antara pengetahuan dengan sikap remaja putri tentang kehamilan remaja di SMK N 2 Tabanan tahun 2018 yaitu sebesar $62,7 \%$.

\section{Referensi}

BKKBN. 2013. Laporan BKKBN tahun 2013. Diakses tanggal 2 Februari 2018

Kisara Bali. 2013. Laporan Kunjungan Remaja 2013. Bali : Kisara.

Notoatmojo. 2010. Metodelogi Penelitian Kesehatan. Jakarta : PT. Rineka Cipta

Sinclair, C., 2012. Buku Saku Kebidanan. Jakarta : ECG

Sugiyono, 2013. Metodelogi Penelitian Pendidikan Pendekatan Kuantitatif. Kuantitatif, dan R \& D. cetakan 16. Bandung : ALFABETA

WHO, 2014. Situasi Kesehatan Reproduksi Remaja Dalam Rangka Hari Keluarga Nasional 29 Juni. Diakses tanggal 4 Februari 2018. 